\title{
Evaluating The Performance Of Transjakarta Bus Stops And Road Section Facilities On The Route Pondok Gede-Pulogadung
}

\author{
Widodo Budi, DERMAWAN \\ Faculty of Engineering, University of Mercu Buana Bekasi, Indonesia \\ wbdermawan@gmail.com \\ Ahmad Rofid, FAZA \\ Faculty of Engineering, University of Mercu Buana Bekasi, Indonesia \\ ahmadrofidfaza1905@gmail.com
}

\begin{abstract}
Jakarta is one of the metropolitan city is also the capital of Indonesia. Over time, Jakarta's growing in terms of population, BPS is projecting an increase in population of $0.73 \%$ of the amount projected in 2018 until 2019 (BPS, 2015). Given this it is necessary also that adequate public transportation to support the mobilization of the daily needs of the residents. One provision of the Public Transport of the Jakarta administration is Transjakarta BRT. This final project aims to determine the load factor, travel time, downtime, waiting time, headways, frequency, circulation time, travel speed, and customer satisfaction on the performance of services that are already on the Transjakarta bus trip Pondok Gede-Pulogadung. The method used is a direct survey on Saturday and Monday from at 6:00 am to 7:00 p.m. WIB.Based results of the analysis already conducted found that, average load factor amounted to 22, 49\%, Downtime for 5.9 minutes, headways is 17 minutes, the frequency of vehicle 3.5 vehicles / hour, the average circulation time is over 248 minutes, the average travel speed is over $13 \mathrm{~km} / \mathrm{h}$. From some of the points mentioned above, the load factor, the time between the frequency of the vehicle, has not been categorized as adequate based on the terms of Minimum Service Standards Transjakarta The time between the average is for 17 minutes, the frequency of vehicle 3.5 vehicles / hour, the average circulation time is over 248 minutes, the average travel speed is over $13 \mathrm{~km} / \mathrm{h}$. From some of the points mentioned above, the load factor, the time between the frequency of the vehicle, has not been categorized as adequate based on the terms of Minimum Service Standards Transjakarta The time between the average is for 17 minutes, the frequency of vehicle 3.5 vehicles / hour, the average circulation time is over 248 minutes, the average travel speed is over $13 \mathrm{~km} / \mathrm{h}$. From some of the points mentioned above, the load factor, the time between the frequency of the vehicle, has not been categorized as adequate based on the terms of Minimum Service Standards Transjakarta.
\end{abstract}

Keywords: BRT Performance, Customer Satisfaction, Transjakarta.

\section{INTRODUCTION}

The metropolitan area is a large population center consisting of over one big metropolis and the surrounding area, or some mutually neighboring central city and the surrounding area. One of the metropolis is the city of Jakarta. Besides regarded as a metropolitan city, Jakarta is also the capital of the State of Indonesia.

Over time, Jakarta's growing in terms of population. BPS has projected an increase in population of $0.73 \%$ of the amount projected in 2018 until 2019 (BPS, 2015)

With the growing population of the city of Jakarta, certainly will result in progress in various fields of industry, education, government, recreation and so on. This then prompted the government to promote public transport as a supporter.

One government-provided public transportation is Transjakarta. Transjakarta bus has been operating since 2004 to support the activities of the capital's increasingly crowded. Transjakarta BRT system is to track the world's longest track along the 230.9 km (Transjakarta, 2019). 
Volume 3 Number 2 Maret 2020

However, with the Transjakarta bus does not make people in Jakarta switch to use it as a means of transportation to support their daily needs. Some residents also still choose to use private vehicles. This phenomenon has become one of the indicators that lead to the city of Jakarta as one of the major cities that have high levels of pollution are high enough (AirVisual, 2019).

Table 1. Minimum Service Standards Transjakarta

Source: SPM Transjakarta, 2017

If the use of public transportation such as bus Transjakarta can be maximized then it certainly will reduce the volume of vehicles that automatically also reduce levels of pollution in the air.

Therefore, researchers wanted to know the extent to which performance of Transjakarta both services and facilities, both from the quality and performance of services and facilities quality Transjakarta buses.

In evaluating the performance and service of the bus must have an indicator. Indicators used is according to Governor Regulation No. 33 Year 2017 on Minimum Service Standards Transjakarta Public Transport Service.

And other ratings are attributes of service, service attributes are attributes of the transportation system that affect customer satisfaction, such as when, where, what, with what mode, which, route doing the movement or travel. Different consumers will consider different service attributes. In reality, consumers do not consider a service attributes that

\begin{tabular}{|c|c|c|}
\hline No. & Criteria & Size \\
\hline 1 & Load factor (Load Factor) & Maximum 95\% \\
\hline \multirow[t]{3}{*}{2} & Time Lapse: & \\
\hline & - Busy time & 7 minutes \\
\hline & - Hours Not Busy & 15 minutes \\
\hline 3 & Passengers Wait Time & 1 minute \\
\hline \multirow[t]{2}{*}{4} & Payment system & \\
\hline & $\begin{array}{l}\text { The availability of payment systems } \\
\text { E-ticketing at every stop trip }\end{array}$ & $100 \%$ \\
\hline 5 & Priority seats Disability & 2-4 Seats \\
\hline 6 & Space for Users Wheelchairs & Minimum 1 Space \\
\hline 7 & Availability Integration Transport & $100 \%$ \\
\hline 8 & Bus travel speed & A maximum of $50 \mathrm{~km} / \mathrm{h}$ \\
\hline 9 & Hours of Service & 17 hours / day \\
\hline
\end{tabular}

exist in a particular type of service, but it describes some of the variables that are considered services biggest influence on the profession (Manheim, 1979).

Some examples of attributes for services in transportation of various considerations, consumers have been formulated by Manheim, 1979 which is considered to represent service to consumers that affect every different consumer activity is as follows

1. Namely the total journey time, reliability, transfer time, frequency of travel, travel time schedule

2. User charges namely direct transportation costs, such as tariffs, cost of equipment, fuel costs and parking fees, other direct operating costs, such as loading and documentation costs, indirect costs, such as maintenance costs, building costs or insurance, travel Frequency

3. Safety and security as the possibility of damage during loading and unloading, the likelihood of accidents, and a feeling of security. 


\section{Volume 03 Number 02 Maret 2020}

4. Fun and convenience of the users of services such as travel distance, the number of exchanges of vehicles, physical comfort, psychological comfort, the other pleasures (ticketing, baggage, food and beverages) and pleasure trips.

5. Expedition services such as insurance, and the right of return shipping.

\section{RESEARCH METHOD}

Figure 1. Research Methodology

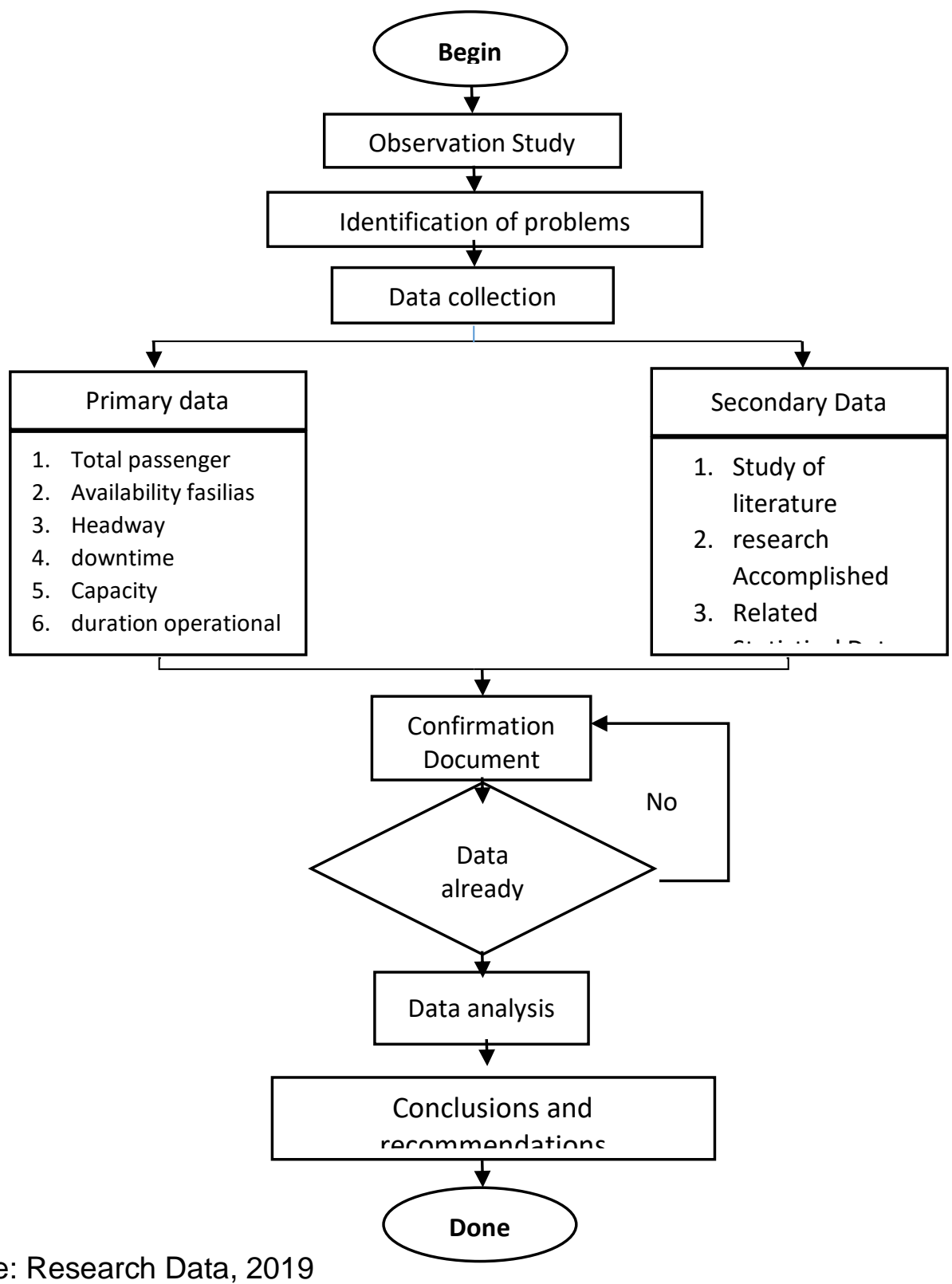

Source: Research Data, 2019

In conducting this study, researchers through several stages that are illustrated in the flow diagram above, which in each process has several activities, among others:

1. Observation area: At this stage, the researchers first observed the area to be observed, the aim is to better identify the scope of the problems and needs that need to be investigated. Things were observed among others as a place of research, bus stops, roads, types of buses, bus users, and others. 
Volume 3 Number 2 Maret 2020

2. Identify the problem: At this stage, researchers will identify the problems of the observations that have been made.

3. Data collection: At this stage, researchers will conduct a search and review the existing data as previous studies, statistical data related and research journals required. In addition to existing data, the researchers also conducted calculations and interviews to obtain data of other data required.

4. Confirmation and Checking Re: At this stage, researchers will conduct confirmation and re-checking of the data that have been collected. Data should be collected in accordance with what is required in the calculations.

5. Data Analysis: At this stage, researchers will perform calculations based on the data that have been collected. In conducting this analysis, researchers used calculation software SPSS and Microsoft Excel.

6. Conclusions and Recommendations: At this stage, the results of the above calculation will be made of a conclusion which will contain the results of the study and suggestions. At this stage the researchers also put an end to the process of flow of research undertaken.

The object of research is something that is a concern in a study, the object of this research were targeted in the research to get the answers or solutions to problems that occur. The object of this research is the evaluation of the performance of roads and Transjakarta bus stop travel route Pulogadung-Pondok Gede.

To obtain the data, this study used multiple data collection techniques, namely:

1. Observations or observation includes observations of various matters relating to the physical condition and activity at the study site.

2. Documentation refers to the gathering and assessment of some information from periodicals, books, literature documents, photographs, newspapers, electronic media and statistical references.

After the survey and the data collection, the next step is to recapitulate and analyze the data that have been obtained. Data on the number of passengers and the capacity of the vehicle used to analyze load factor. The amount of data obtained from observations and giving questionnaires to the respondents.

\section{RESULTS AND DISCUSSION}

With the results of the analysis and the count that has researchers did, that there are several points that describe in the implementation of the daily performance, $4 \mathrm{~F}$ These Transjakarta bus is quite satisfactory, here are the results.

Table 2. Summary of Analysis Results

\begin{tabular}{|c|c|c|c|c|}
\hline No. & $\begin{array}{l}\text { Bus Services Performance } \\
\text { Indicators }\end{array}$ & $\begin{array}{l}\text { Minimum } \\
\text { Service } \\
\text { Standards }\end{array}$ & $\begin{array}{l}\text { Results } \\
\text { Analysis } \\
\text { Survey } \\
\text { Data }\end{array}$ & Information \\
\hline 1 & Load factor (Load Factor) & $\begin{array}{l}\text { Maximum } \\
95 \%\end{array}$ & $22.49 \%$ & have adequate \\
\hline 2 & Time Lapse: & $\begin{array}{l}7-15 \\
\text { minutes }\end{array}$ & $\begin{array}{l}17 \\
\text { minutes }\end{array}$ & Inadequate \\
\hline 3 & Passengers Wait Time & $\begin{array}{l}\text { Maximum } \\
1 \text { min / } \\
\text { stop }\end{array}$ & 6 minutes & have adequate \\
\hline 4 & Payment system & $100 \%$ & $100 \%$ & have adequate \\
\hline
\end{tabular}


Volume 03 Number 02 Maret 2020

\begin{tabular}{|c|c|c|c|c|}
\hline & $\begin{array}{l}\text { The availability of payment } \\
\text { systems } \\
\text { E-ticketing at every stop trip }\end{array}$ & & & \\
\hline 5 & Priority seats Disability & 2-4 Seats & 2 Seats & have adequate \\
\hline 6 & Space for Users Wheelchairs & $\begin{array}{l}\text { Minimum } \\
1 \text { Space }\end{array}$ & 1 space & have adequate \\
\hline 7 & $\begin{array}{l}\text { Availability } \\
\text { Transport }\end{array}$ & $100 \%$ & $100 \%$ & have adequate \\
\hline 8 & Bus travel speed & $\begin{array}{l}\text { A } \\
\text { maximum } \\
\text { of } 50 \mathrm{~km} \mathrm{/} \\
\mathrm{h} \text { (except } \\
\text { in tolls) }\end{array}$ & $\begin{array}{l}\text { A } \\
\text { maximum } \\
\text { of } 42.1 \mathrm{~km} \\
/ \mathrm{h}\end{array}$ & have adequate \\
\hline 9 & Hours of Service & $\begin{array}{l}17 \text { hours / } \\
\text { day }\end{array}$ & $\begin{array}{l}17-19 \\
\text { hours } \\
\text { day }\end{array}$ & have adequate \\
\hline
\end{tabular}

Source: Research Data, 2019

Time headway of itineraries Transjakarta Pulogadung and Pondok Gede still not fulfilled any of the terms that have been set minimum service standards. But in addition to the performance indicators, eight other indicators have been fulfilled properly.

With the results of the analysis and the count that has the researcher Total Respondents were sampled for this questionnaire data is a total of 110 respondents, the questionnaire data dissemination is divided into two ways, online and face to face.

Here are some characteristics that researchers have received from the respondents.

Figure 2. Graph Percentage of Respondents' Gender

\section{Apa jenis kelamin anda? \\ 110 responses}

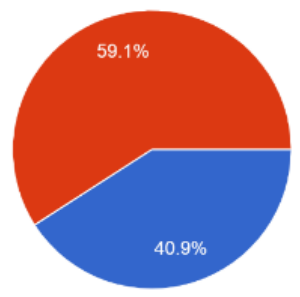

- Laki-laki

Perempuan

Source: Survey Results, 2019

From the results of questionnaires received, the amount of more female respondents (65 respondents) with a percentage of $59.1 \%$ and male respondents (45 respondents) with a percentage of $40.9 \%$. 
Volume 3 Number 2 Maret 2020

Figure 3. Graph Percentage of Respondents Age

Dikisaran usia berapakah anda?

110 responses
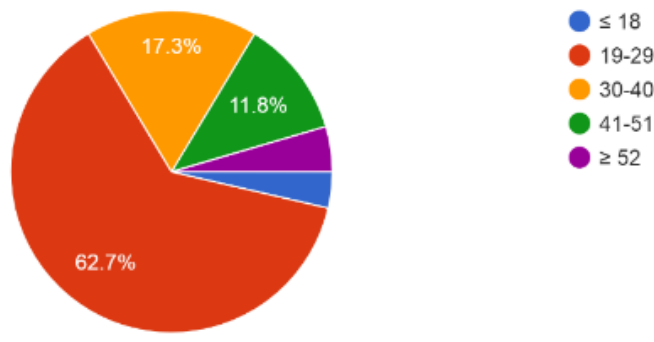

Source: Survey Results, 2019

The age range of the respondents is quite varied, with ages ranging from 19-29 years most dominating with a total of 69 respondents $(62.7 \%)$ and ages ranging from less than or equal to 18 years is as much as 4 respondents (3.6\%).

Figure 4. Graph Percentage of Employment or Activities

Pekerjaan atau aktivitas sehari-hari?

110 responses

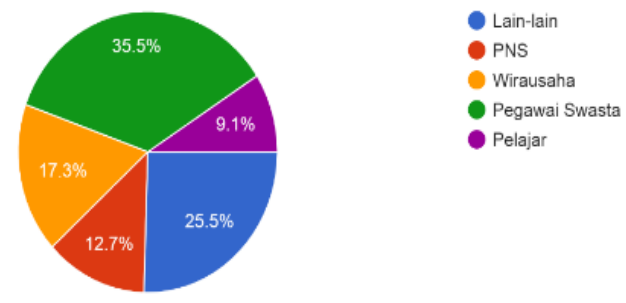

Source: Survey Results, 2019

From work or daily activities, the respondents have a variety of daily life, with the percentage of activity or other work as much as $25.5 \%$ (28 respondents), the dominator of the students were respondents aged less than or equal to 18 years. 


\section{Volume 03 Number 02 Maret 2020}

Figure 5. Graph Percentage of Use

Berapakali anda menggunakan jasa Bus Transjakarta dalam seminggu? 110 responses

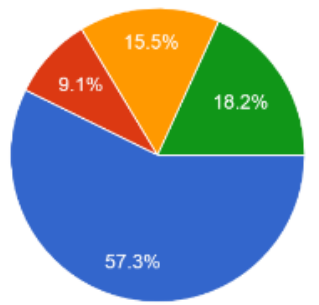

Source: Survey Results, 2019

And to the use of daily repetition, much less than or equal to 3 days a week were 63 respondents (57.3\%), greater than or equal to 5 days a week by 20 respondents $(18.2 \%)$, 4-5 days a week as 17 respondents (15.5\%), and 3-4 days a week by 10 respondents $(9.1 \%)$.

a. Validity test

In a test of validity, the necessary weighting value of quality of service to customers in advance to every question in every scale. The function of the validity of the test is to measure the accuracy of existing research instruments, whether it can be considered valid or not.

Rated $\mathrm{R}$ obtained from simple correlation coefficient table for a significant level of $5 \%$ with a total sample of 108 (110-2) obtained 0.1874 .

Table 2. Table $R$

\begin{tabular}{llllll}
\hline DF $=(\mathrm{n}-2)$ & \multicolumn{5}{l}{ Significant Level Two Directions } \\
& 0.1 & $\mathbf{0 . 0 5}$ & 0.02 & 0.01 & 0,001 \\
\hline $\mathbf{1 0 5}$ & .1599 & .1900 & .2247 & .2480 & .3137 \\
$\mathbf{1 0 6}$ & .1591 & .1891 & .2236 & .2469 & .3123 \\
$\mathbf{1 0 7}$ & .1584 & .1882 & .2226 & .2458 & .3109 \\
108 & .1576 & .1874 & .2216 & .2446 & .3095 \\
$\mathbf{1 0 9}$ & .1569 & .1865 & .2206 & .2436 & .3082 \\
$\mathbf{1 1 0}$ & .1562 & .1857 & .2196 & .2425 & .3068 \\
\hline
\end{tabular}

(Source: Survey, 2019)

Then, the results of calculations using SPSS 26 software, obtained the following results

Table 4. Comparison of $R$ Count

\begin{tabular}{lll}
\hline No. & $\begin{array}{l}\text { R. Calculate the } \\
\text { results SPSS }\end{array}$ & $\begin{array}{l}\text { R. } \\
\text { Results Table }\end{array}$ \\
\hline 1 & .740 & .1874 \\
2 & .740 & .1874 \\
3 & .740 & .1874 \\
4 & .749 & .1874 \\
5 & .654 & .1874 \\
6 & .810 & .1874 \\
7 & 0,800 & .1874 \\
8 & 0.776 & .1874 \\
9 & 0,711 & .1874 \\
10 & .642 & .1874 \\
\hline
\end{tabular}




\begin{tabular}{lll}
\hline 11 & 0.741 & .1874 \\
12 & 0.754 & .1874 \\
13 & 0,745 & .1874 \\
14 & 0.724 & .1874 \\
15 & 0.775 & .1874 \\
16 & 0,795 & .1874 \\
17 & 0,844 & .1874 \\
18 & .807 & .1874 \\
19 & .780 & .1874 \\
20 & .681 & .1874 \\
\hline \multicolumn{2}{c}{ Source: Survey Results, 2019 }
\end{tabular}

From Table 4 contains comparative tables obtained that $r r$ count larger table results compared with $r$ table. So the instrument on a questionnaire created can be declared invalid.

b. test Reliability

To test the reliability of the data, can be carried out under the following conditions

1. If the value of Cronbach's Alpha> 0.60 then the questionnaire or questionnaires can be declared reliable or consistent.

2. Meanwhile, if the value of Cronbach's Alpha $<0.60$ then the questionnaire or questionnaires can be declared unreliable or inconsistent.

Cronbach's Alpha reliability test serves to test the level of confidence in the consistency, so the questionnaire or reliable research questionnaire to measure the variables of the study, although the study was conducted repeatedly with the same questionnaire or questionnaire. 
Volume 03 Number 02 Maret 2020

Table 5. Table Test Reliability Cronbach Alpha SPSS

\begin{tabular}{|c|c|c|c|c|}
\hline \multicolumn{5}{|c|}{ Item-Total Statistics } \\
\hline & $\begin{array}{l}\text { Scale Mean if } \\
\text { Item Deleted }\end{array}$ & $\begin{array}{c}\text { Scale } \\
\text { Variance if } \\
\text { Item Deleted }\end{array}$ & $\begin{array}{l}\text { Corrected } \\
\text { Item-Total } \\
\text { Correlation }\end{array}$ & $\begin{array}{l}\text { Cronbach's } \\
\text { Alpha if Item } \\
\text { Deleted }\end{array}$ \\
\hline $\mathrm{X} 1$ & 65,57 & 125,586 & 669 &, 945 \\
\hline $\mathrm{X} 2$ & 65,33 & 126,956 &, 640 &, 945 \\
\hline $\mathrm{X} 3$ & 65,12 & 125,775 & 603 & 946 \\
\hline $\mathrm{X} 4$ & 65,25 & 124,320 &, 656 & 945 \\
\hline$\times 5$ & 65,45 & 126,158 &, 550 & 947 \\
\hline$x_{6}$ & 65,22 & 125,328 &, 690 & 944 \\
\hline $\mathrm{X} 7$ & 65,45 & 122,469 &, 757 & 943 \\
\hline $\mathrm{x} 8$ & 65,19 & 125,404 & ,655 & 945 \\
\hline$\times 9$ & 65,20 & 125,538 &, 679 &, 945 \\
\hline $\mathrm{X} 10$ & 65,65 & 123,882 & ,633 &, 945 \\
\hline $\mathrm{Y} 1$ & 65,29 & 125,438 &, 721 & 944 \\
\hline Y2 & 65,16 & 125,111 & ,696 &, 944 \\
\hline Y3 & 65,18 & 122,811 &, 731 &, 944 \\
\hline$Y_{4}$ & 65,45 & 125,020 &, 655 &, 945 \\
\hline Y5 & 65,22 & 124,392 & 662 & 945 \\
\hline Y6 & 65,13 & 124,718 &, 702 & 944 \\
\hline Y7 & 65,33 & 123,085 &, 768 &, 943 \\
\hline Y8 & 65,29 & 123,346 &, 700 &, 944 \\
\hline Y9 & 65,49 & 123,316 &, 644 &, 945 \\
\hline Y10 & 65,38 & 127,229 &, 617 & ,945 \\
\hline
\end{tabular}

\begin{tabular}{|c|c|}
\hline \multicolumn{2}{|c|}{ Reliability Statistics } \\
\hline $\begin{array}{c}\text { Cronbach's } \\
\text { Alpha }\end{array}$ & $\mathrm{N}$ of Items \\
\hline 947 & 20 \\
\hline
\end{tabular}

\begin{tabular}{|c|c|c|c|}
\hline \multicolumn{4}{|c|}{ Case Processing Summary } \\
\hline & & $\mathrm{N}$ & $\%$ \\
\hline \multirow[t]{3}{*}{ Cases } & Valid & 110 & 100,0 \\
\hline & Excluded $^{\mathrm{a}}$ & 0 & 0 \\
\hline & Total & 110 & 100,0 \\
\hline a. $\mathrm{Li}$ & $\begin{array}{l}\text { Nise deletior } \\
\text { bles in the }\end{array}$ & $\begin{array}{l}\text { sed on a } \\
\text { dure. }\end{array}$ & \\
\hline
\end{tabular}

Source: Survey Results, 2019

So we get the test results Cronbach alpha reliability of 0.947 (above the minimum 0.6) from which we can conclude that all the instruments in this study can be considered reliable or consistent

c. Chi Square test

Chi Square is also called Kai Squares. Chi Square is one type of non-parametric comparative test conducted on two variables. This analysis technique using a comparison of two variables to analyze the observed frequencies with the expected frequencies.

From the results of chi square using the following rules:

1. If $X^{2}$ count $>X^{2}$ table, then Ho is rejected.

2. If $X^{2}$ count $<X^{2}$ table, then Ho is accepted

The factors that observation is the average level of performance appraisal customer service and satisfaction.

Table 6. Table Average Service Performance

\begin{tabular}{|c|c|c|c|c|c|}
\hline \multirow{2}{*}{$\begin{array}{l}\text { Service } \\
\text { performance }\end{array}$} & \multicolumn{4}{|c|}{ Values questionnaire } & \multirow{2}{*}{$\begin{array}{l}\text { Total } \\
\text { value }\end{array}$} \\
\hline & 12 & 3 & 4 & 5 & \\
\hline 1 & 15 & 67 & 20 & 8 & 110 \\
\hline 2 & 4 & 66 & 29 & 11 & 110 \\
\hline 3 & 5 & 51 & 33 & 21 & 110 \\
\hline
\end{tabular}




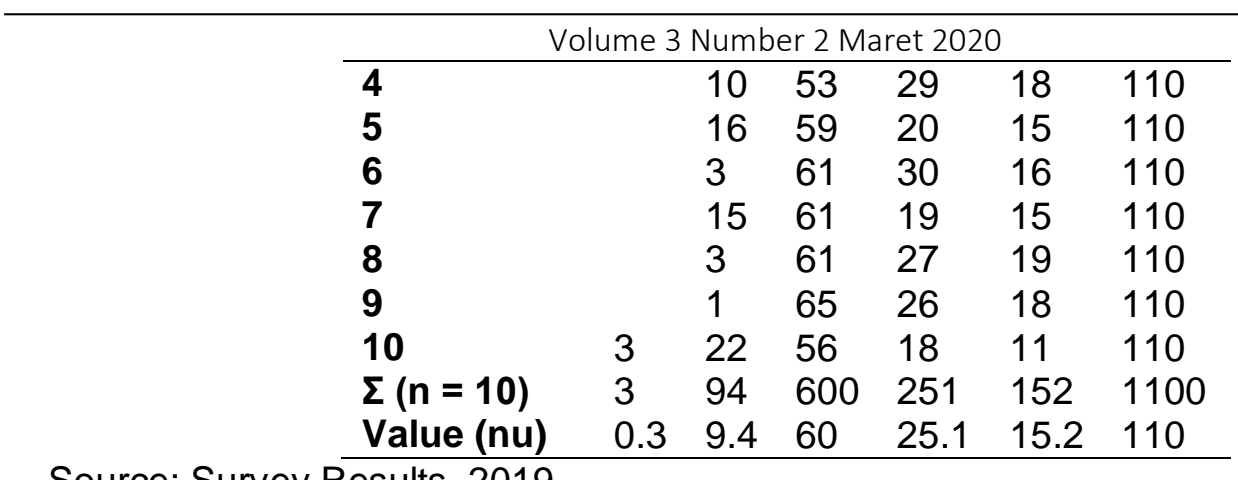

Source: Survey Results, 2019

Table 7. Table Average Customer Satisfaction

\begin{tabular}{|c|c|c|c|c|c|c|}
\hline \multirow{2}{*}{$\begin{array}{l}\text { Customer } \\
\text { satisfactio } \\
n\end{array}$} & \multicolumn{5}{|c|}{ Values questionnaire } & \multirow{2}{*}{$\begin{array}{l}\text { Total } \\
\text { value }\end{array}$} \\
\hline & 1 & 2 & 3 & 4 & 5 & \\
\hline 1 & & 2 & 69 & 25 & 14 & 110 \\
\hline 2 & & 5 & 50 & 40 & 15 & 110 \\
\hline 3 & & 1 & 55 & 29 & 25 & 110 \\
\hline 4 & 1 & 11 & 63 & 23 & 12 & 110 \\
\hline 5 & 1 & 6 & 54 & 31 & 18 & 110 \\
\hline 6 & & 2 & 57 & 31 & 20 & 110 \\
\hline 7 & & 8 & 63 & 23 & 16 & 110 \\
\hline 8 & & 10 & 58 & 23 & 19 & 110 \\
\hline 9 & 4 & 13 & 57 & 22 & 14 & 110 \\
\hline 10 & & 5 & 70 & 24 & 11 & 110 \\
\hline$\Sigma(n=10)$ & 6 & 63 & 596 & 271 & 164 & 1100 \\
\hline Value (eu) & 0.6 & 6.3 & 59.6 & 27.1 & 16.4 & 110 \\
\hline
\end{tabular}

Then, after the value of the average (mean) is obtained, the next step is to find $X^{2}$ count. Table 8. Table $\mathrm{X}^{2}$ arithmetic

\begin{tabular}{llllll}
\hline Score & $(\mathrm{Nu})$ & $(\mathrm{Eu})$ & $(\mathrm{Nu}-\mathrm{eu})$ & $(\mathrm{Nu}-\mathrm{eu})^{2}$ & $(\mathrm{Nu}-\mathrm{eu})^{2} / \mathrm{eu}$ \\
\hline 1 & 0.3 & 0.6 & -0.3 & 0.09 & .150 \\
2 & 9.4 & 6.3 & 3.1 & 9.61 & 1,525 \\
3 & 60 & 59.6 & 0.4 & 0.16 & 0,003 \\
4 & 25.1 & 27.1 & -2 & 4.00 & 0.148 \\
5 & 15.2 & 16.4 & -1.2 & 1.44 & 0.088 \\
$\Sigma$ & 110 & 110 & 0 & 15.30 & 1,913 \\
\hline
\end{tabular}

Source: Survey Results, 2019

From the above calculation found that the value of $X^{2}$ is 1,913 with significant value by $5 \%$ and the number of service factors were observed as many as 10 with the scale value of 5 pieces, then calculated to find Table $X^{2}$ is $\alpha=5 \%, k=10, p=5$

$$
\begin{aligned}
\text { Degrees of freedom }(\mathrm{df}) & =(\mathrm{K}-1) \times(\mathrm{h}-1) \\
& =(10-1) \times(5-1) \\
& =36
\end{aligned}
$$

Table 9. Table $P$ Value

\begin{tabular}{llllll}
\hline DF $=(n-2)$ & \multicolumn{1}{l}{ P value (Level Significant) } & & & \\
& 0.1 & 0.05 & 0.02 & 0.01 & 0,001 \\
\hline 33 & 43745 & 47,400 & 51743 & 54776 & 63870 \\
34 & 44903 & 48602 & 52995 & 56061 & 65247 \\
\hline
\end{tabular}




\begin{tabular}{llllll}
\hline \multicolumn{5}{c}{ Volume 03 Number 02 Maret 2020 } \\
\hline 35 & 46059 & 49802 & 54244 & 57342 & 66619 \\
36 & 47212 & 50998 & 55489 & 58619 & 67985 \\
37 & 48363 & 52192 & 56730 & 59893 & 69346 \\
38 & 49513 & 53384 & 57969 & 61162 & 70703 \\
\hline
\end{tabular}

(Source: Survey, 2019)

Rated $X^{2}$ The table is obtained from the table Chi Square for the $5 \%$ probability level with the degrees of freedom of 36 earned 50.998 .

So that these results can be concluded that the value of $X^{2}$ hitung $(1,913)$ is smaller than the result $X^{2}$ tabel (50.998), then $\mathrm{Ho}$ is accepted which means that the service performance (Independent) did not significantly affect customer satisfaction (dependent).

Figure 6. Figure Rejection Region $\mathrm{HO}$

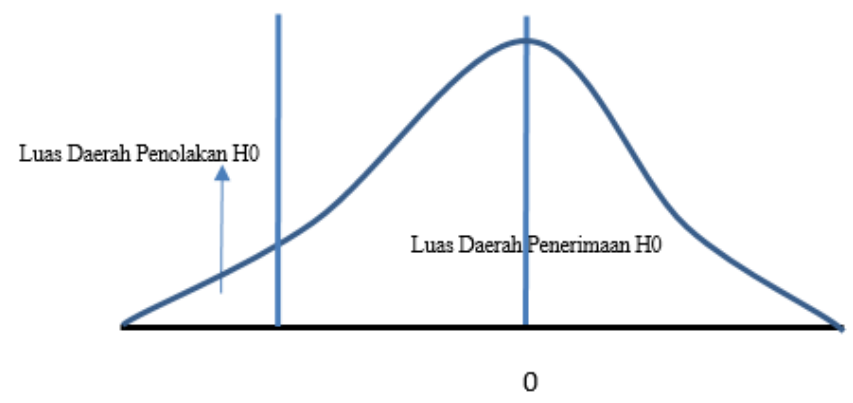

Source: Survey Results, 2019

\section{CONCLUSION}

After analyzing the data obtained through surveys and questionnaires, we can conclude based on the regulations and rules set DKI Jakarta Governor Regulation No. 33 Year 2017 on Minimum Service Standards Transjakarta Public Transport Service, then:

1. S capacity 4F Transjakarta bus trip from Pulogadung to Pondok Gede and otherwise use the Bus output of Mercedes Benz and Scania with a total seating capacity to seat 40 and the stand by 26 , bringing the total capacity of the bus is 66.

2. Load factor is as much as 10.52 rit fewest Pondok Gede journey towards Pulogadung that occurred on Monday, December 16, 2019, while the load factor occurred in the day Saturday, December 21, 2019 to 34.57 Pulo Gadung travel route to Pondok Gede. The average load factor that the researchers observed was 22.49 from the results for the $269.95 / 12$ rit.

3. The average travel time is 59.5 minutes trip, the longest trip is 82 minutes maximum.

4. Passenger waiting time was 6 minutes

5. Headway time average is equal to 17 minutes with the longest headway time is 48 minutes and the fastest is 3 minutes.

6. The frequency of bus arrivals per hour happens is as much as 3.5 which results from a $59.5 / 17 \mathrm{~min}$ 
Volume 3 Number 2 Maret 2020

7. Time average circulation amounted to 248,18 minutes with the longest circulation time is $\mathbf{2 8 8}$ minutes which occurred at rush hour home from work, and the fastest circulation time was 194 minutes which occurred at lunchtime lunch break.

8. Average travel speed of travel of Pulogadung stop - stop Pondok Gede is 12.57 $\mathrm{km} / \mathrm{h}$, in the opposite direction has an average speed of $13.54 \mathrm{~km} / \mathrm{h}$. The overall average total trip is $13.059 \mathrm{~km} / \mathrm{h}$.

9. Service time taken is around 19 hours / day

10. That the service performance and customer satisfaction received are considered independent.

\section{REFERENCES}

Bowersox, C., (1981), Introduction to Transportation, Macmillan Publishing, Newyork. Dagun, Save M., (2016), Busway, Breakthrough Treatment Transportation Jakarta, Pustaka Sinar Harapan, Jakarta

Governor Regulation. (2017), Minimum Service Standards Transjakarta Public Transport Services "inhttps://peraturan.bpk.go.id/ (Accessed on 10 February 2020).

Susantono, Bambang., (2014), Transport Revolution, Gramedia, Jakarta.

Salim Abbas., (1993), Transportation Management, Jakarta, Indonesia Ghalia.

Tobing, Fenny, et al., (2014), Customer Satisfaction Analysis of the Transjakarta Bus Services (Case Study Tamini Garuda Corridor IX), Economic Bulletin Scientific Journal ISSN: 1410-3842 Volume 18 No. August 2nd, 2014, the Christian University of Indonesia, Jakarta

Transjakarta. (2019), Product and Service Bus Transjakartahttps://Transjakarta.co.id/ (Accessed on 10 September 2019).

Visual Water, (2019). Jakarta Water Quality And Daily Weather Forecast inhttps://airvisual.com/ (Accessed on 10 September 2019).

Vuchic, VR (1981), "Urban Public Transportation Systems and Technology", Prentice 